\title{
A MODIFICATION OF MITSCHERLICH'S METHOD FOR THE DETERIMINATION OF THE NUTRIENT CONTENTS OF A SOIL
}

\author{
By Bernardo G. Capó. \\ (Graphs and Diagrams by Fernando Chardón.)
}

\section{INTRODUCTION}

To find the relation that exists between the concentrations of plant nutrients in a soil and the yield of the crop planted in it, has been for a long time one of the main problems tackled by agricultural ehemists all the world over. Among the many investigators who have worked along this line, E. A. Mitscherlich has startled his colleagues by making a series of bold assertions with respect to this problem.

Mitscherlich's theories have been both attacked and defended with too much zeal. In fact, in many cases the scientific point of view has been overlooked, and both attackers and defenders have arbitrarily discarded data which would prove unsatisfactory for their own point of view.

To determine to just what extent Mitscherlich's theories apply to plants grown under Puerto Rican conditions and the possibility of the application of said theories to the furtherance of Puerto Rican agrieulture have been objects which the author has tried to attain in complying with the requisites of the project under which this work has been performed.*

\section{Mitscherlich's Theories}

Mitscherlich has stated that the relation beiween the initial concentration of any given plant nutrient in a given soil and the yield of the plants grown in it may be represented by an equation of the type:

$$
\mathrm{y}=\mathrm{A}\left(1-\mathrm{K}^{\mathrm{x}}\right)
$$

where " $y$ " is the yield of the crop obtained with the initial coneentration " $x$ " of the plant nuirient, " $A$ ", is the maximum yield obtainable with unlimited increases in the initial concentration of said plant nutrient, and " $\mathrm{K}$ " is a constant corresponding to the nutrient under study.

* This work has been performed under Project No. 2, Bankhead-Jones Fund. 
To calculate the values of the constants " $A$ " and " $\mathrm{K}$ " which are applicable to a given set of conditions, it is necessary to know at least the yields produced, under the required set of conditions, with two different initial concentrations of the plant nutrient. The corresponding values for " $x$ " and " $y$ " are substituted in equation (1) above, and the resulting equations are solved for " $A$ " and " $K$ ".

If only the yields produced with two different initial concentrations of the plant nutrient are known, the substitutions will provide only two equations in the two unknowns " $A$ " and " $K$ ". These are solved, therefore, simultaneously.

If the yields produced with more than two different initial concentrations of the plant nutrient are known, the substitutions will provide more than two equations in the two unknowns " $A$ " and " $K$ ". These should be solved, therefore, by the Method of Least Squares in order to obtain the most probable values of the constants "A" and " $\mathrm{K}$ ".

With the values of " $\mathrm{A}$ " and " $\mathrm{K}$ " as obtained by either of the two methods referred to above, an equation of the type of equation (1) may be written to express the relation that exists between the initial concentration of the plant nutrient and the yield of the crop which is produced in its presence under the given set of conditions. With this equation it is possible to calculate the yield of the crop which would be produced, under this set of conditions, by any initial concentration of the plant nutrient.

However, the equation which shows the relation between the initial concentration of a nutrient in a given soil, with its own set of climatic conditions, and the yield of the crop planted in it must also provide for the specific available nutrients in that soil.

The equation is therefore, modified into one of the type

$$
\mathrm{y}=\mathrm{A}\left(1-\mathrm{K}^{\mathrm{b}+\mathrm{x}} ;\right.
$$

where " $y$ ", "A" and " $\mathrm{K}$ " mean the same as in equation (1), and now " $b+x$ " is the initial nutrient concentration; " $b$ " being the respective nutrient concentration in the unmanured soil and " $x$ " the increase in nutrient concentration produced by the addition to the soil of materials containing said nutrient.

This equation contains, therefore, three constants or parameters whose values must be determined. In order that the values of these constants may be calculated it is necessary that at least three yields produced with three different applications of the nutrient be known. 
If only three such values are known, due substitutions for " $x$ " and " $y$ " are made in equation (2) and the resulting three equations solved simultaneously in order to find the values of "A", " $K$ " and "b".

If more than three yield values with the corresponding nutrient applications in whose presence they were produced are known, the substitutions in equation (2) will furnish more than three equations in these three unknowns and these equations must then be solved by the Method of Least Squares in order to obtain the most probable values of the constants " $A$ ", " $K$ " and " $b$ ".

The value of " $b$ " found in either of these ways is therefore the nutrient content of this soil for this respective nutrient. The application of equation (2), therefore, affords a method for the determination of the content by a soil of any given plant nutrient.

This method requires: the application to given equal amounts of soil, of three different amounts of the plant nutrient under study, the growth of a crop in each of these soil portions, the weighing of these crops, the substitution of the values of nutrient applications and corresponding crop yields for " $\mathrm{x}$ " and " $\mathrm{y}$ " respectively in equation (2), and the mathematical solution of these equations for " $b$ ".

This means that for the determination of the content by the soil of any plant nutrient, in a form as available to a given plant as the form in which the plant nutrient is used, an experiment must be performed with at least three different applications of said plant mutrient in the desired form. If it is required to determine the soil contents of the three principal nutrients, (nitrogen, phosphoric acid and potash), it is necessary that one of such experiments be performed with each of these plant nutrients, making a total of nine different treatments. Three of these treatments may be equal, reducing the total number to seven treatments. With this procedure, therefore, it is possible to calculate the soil contenis of the three principal plant nutrients.

Mitscherlich has announced, however, that the constant " $\mathrm{K}$ ", corresponding to a plant nutrient is the same for all crops'and in all soils. He has stated, in fact, that the following values hold for these nutrients under all conditions, when the nutrient amounts are expressed in doublezentners per hectare:

For ammonia $\left(\mathrm{NH}_{3}\right)$ :

For phosphoric acid $\left(\mathrm{P}_{2} \mathrm{O}_{5}\right)$ :

For potash $\left(\mathrm{K}_{2} \mathrm{O}\right)$, sodium present:

For potash $\left(\mathrm{K}_{2} \mathrm{O}\right)$, sodium absent:

$$
\begin{aligned}
& K=10^{0.10} \\
& K=10^{0.60} \\
& K=10^{0.93} \\
& K=10^{0.33}
\end{aligned}
$$


The constancy of these "effect factors", as claimed by Mitscherlich, led him to devise a simplification of the experimental scheme described above. Since the values for the different " $K$ 's" are fixed, the determination of the soil content of a plant nutrient can be done with only two different applications of said plant nutrient, since the values of only the two parameters "A" and "b" must be found. For the study of the soil contents of all three principal nutrients a total of six different treatments would be required, which number reduces to only four different treatments, since three of the six treatments may be equal. In this way the procedure of finding the nutrient contents of a soil is very simple. If to this is added the fact that these experiments can be performed with advantage in pots, where the conditions under which all treatments act may be carefully controlled, this procedure may afford a most simple and accurate method to do these determinations. Only one requisite is lacking. That it will work. Which leads us to our experimental work, which began with some experiments designed to determine whether this simple procedure gives reliable results.

\section{Experimental Work}

To date ten different pot experiments and one field experiment have been performed in five different soil types. The field experiment was performed on a field from which a soil sample had been taken for a pot experiment. The corresponding pot and field experiments thus check one another and their results serve as indications of the reliability which may be put on ihe results of pot tests of the type here preferred. These two experiments are the ones which will be presented as the experimental work on which the conclusions obtained from this work have been mainly based. The results of ihe other pot experiments, and of a field experiment performed with eggplants at the Isabela Sub-Station farm following the plan used in our field experiment, are in line and corroborate fully the conclusions derived from the two experiments presented here.

\section{Pot Experiment With Vega Baja Silty Clay}

The Vega Baja silty clay consists of a slightly mottled alluvial gray brown top soil lying over yellow brown and red mottled stiff clay. The soil sample for this experiment was taken from field $1 \mathrm{D}$ 
of the Station farm, where the field experiment that follows this one was established. The soil was air dried and sieved through a 0.25 inch diameter circular hole sieve. The sieved soil was well mixed and one kilogram samples taken for each pot. Nitscherlich's enameled pots with circular opening's at the bottom with capacity for 6 kilogram samples were used. The one kilogram of soil for each pot was mixed with 5 kilograms of Corozos sand and with the appropriate amounis of the nutritive salts before being transferred to the corresponding pot. The Corozos sand, a white quartz type of sand, was unwashed, but rapid chemical tests showed that it contained no nitrates, nor ammonium salts, no potash and only traces of phosphoric acid. This experiment was performed with Hegari Sorghum, a crop which previous pot tests had demonstrated to be the best among a series of standard grain and grass varieties as regards germination, speed of growth and freedom from disease and insect attacks, under greenhouse conditions at the Station.

Due to the good germinating power of the seeds only 40 seeds were planted in each pot, and 35 plants were allowed to grow until harvest time. The thimning was done on the fourth day after planting, the plants being already about $1 \frac{1}{2}$ inches high. Due to the rapid growth of the plants, Mitscherlich's watering procedure was varied. During the first days after planting the weight of each pot was raised by $200 \mathrm{~g}$. daily, later on by $100 \mathrm{~g}$. daily, then by $50 \mathrm{~g}$. and finally by $25 \mathrm{~g}$. daily until full water capacity was reached for each pot. After the water content of a pot had been brought to full water capacity the increases in weight were reduced to only 10 grams. That is, when it was found that a pot dripped, its weight was brought with distilled water to the same weight as on the previous day. If no water had percolated to the pan beneath, the weight of the pot was raised with distilled water by 10 grams. In this way the water content of each pot was brought to full water capacity every day.

The crop was harvested when the plants were about to head, that is, at the end of the vegetative period. On harvesting, all the material above the soil in each pot was cut with shears into pieces of about 1 inch in length and placed in a tared and numbered wire basket. The plant material was then dried to constant weight in a constant temperature electric oven at a temperature of about $115^{\circ} \mathrm{C}$. Constant we.ght was assumed to be arrived at when the basket did not lose more than 0.1 gram after being in the oven for 3 additional hours. Table I summarizes the results of this experiment. 


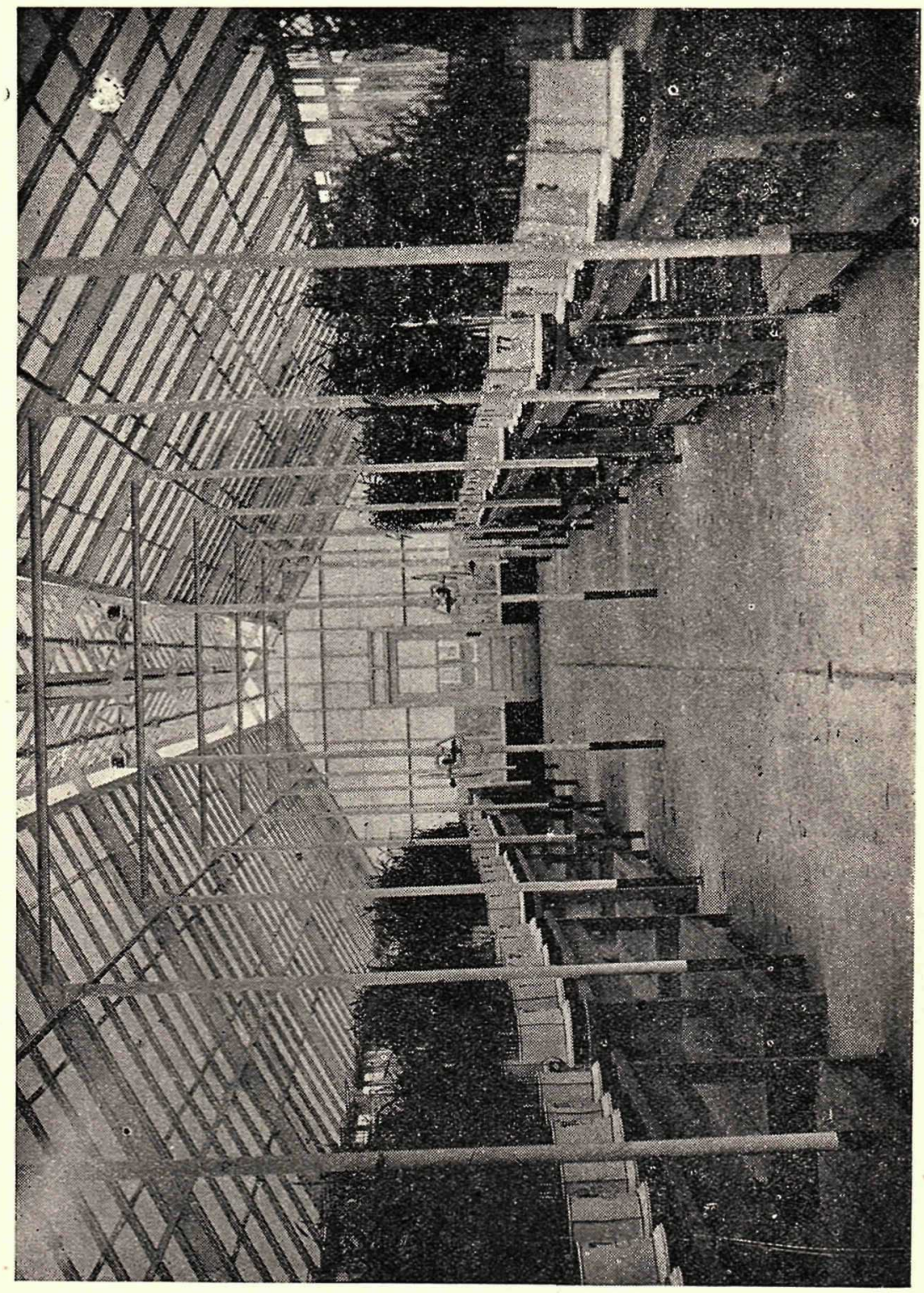

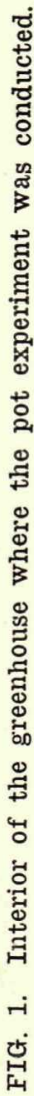




\begin{tabular}{|c|c|c|c|c|c|c|c|c|}
\hline \multicolumn{4}{|c|}{ Treatments (in grams of substance per pot) } & \multicolumn{5}{|c|}{ Yield (in grams of dry-matter per pot) } \\
\hline \multirow[b]{2}{*}{ No. } & \multirow[b]{2}{*}{$\mathrm{NH}:$} & \multirow[b]{2}{*}{$\mathrm{P}: \mathrm{O}_{5}$} & \multirow[b]{2}{*}{$\mathrm{K}: \mathrm{O}$} & \multicolumn{4}{|c|}{ Replications } & \multirow[b]{2}{*}{ A verage } \\
\hline & & & & 1st & 2ud & $3 \mathrm{rd}$ & 4 th & \\
\hline 1. & 1. 0227 & 0.1893 & 0. 0000 & 31.0 & 25.6 & 27.9 & 27.0 & 27.9 \\
\hline 2. & 1. 0227 & 0.1893 & 0.1218 & 32.6 & 33. 1 & 36.1 & 37.3 & 34.8 \\
\hline & 1. 0227 & 0.1893 & 0.2436 & 430 & 40.2 & 37.5 & 42.3 & 40.8 \\
\hline …....... & 1. 0227 & 0.0000 & 0.3654 & 133 & 11. 9 & 11.2 & 11. 6 & 12.0 \\
\hline $5 .$. & 1. 0227 & 0.0631 & 0.3654 & $25 . \hat{3}$ & 24.3 & 25.9 & 25.8 & 25.3 \\
\hline & 1. 0227 & 0.1262 & 0.3654 & 38.8 & 36.3 & 34.7 & 33.2 & 35.8 \\
\hline & 0.0000 & 0.1893 & 0.3654 & 10.5 & 10.1 & 10.4 & 10.3 & 10.3 \\
\hline .......... & 0.3409 & 0.1893 & 0.3654 & 39.2 & 35.9 & 36.3 & 36.0 & 36.8 \\
\hline ............. & 0.6818 & 0.1893 & 0.3654 & 44.1 & 45. 0 & 41.5 & 39.4 & 42.5 \\
\hline …… & 1. 0227 & 0.1893 & 0.3654 & 42.7 & 48.8 & 53.4 & 44.9 & 47.4 \\
\hline ............. & 0.3409 & 0.0631 & 0.1218 & 20.8 & 21.8 & 21.8 & 21.7 & 21.5 \\
\hline$\cdots ; \cdots$ & 0.6818 & 0.1262 & 0.2436 & 41.4 & 34.9 & 35.0 & 31.8 & 37. 6 \\
\hline
\end{tabular}

Table I.-Results of the Pot Experiment with Hegari Sorghum in Vega Baja silty clay.

Interpretation $0^{*}$ the Results of the Pot Experiment: (a) The equation of the type of equation (2) above which fits best the average results obtained with treatments $1,2,3$ and 10 is

$$
\mathrm{y}=894.6\left(1-0.94005^{0.5163+\mathrm{x}}\right) \text {. }
$$

This means that in this soil there are 0.5163 g. $\mathrm{K}_{2} \mathrm{O}$ per kilogram in a form as available to the plants as the $\mathrm{K}_{2} \mathrm{O}$ in $\mathrm{K}_{2} \mathrm{SO}_{4}$, which was the salt used to furnish the $\mathrm{K}_{2} \mathrm{O}$ in this experiment. The fit between th actual yields obtained and those calculated by making use of equation (3) may be observed in Table II and Graph I.

\begin{tabular}{|c|c|c|}
\hline \multirow[b]{2}{*}{ Grams $\mathrm{K} O$ added per pot } & \multicolumn{2}{|c|}{$\begin{array}{l}\text { Yields (in grams of } \\
\text { dry-matter per pot }\end{array}$} \\
\hline & Actual & Calculated \\
\hline 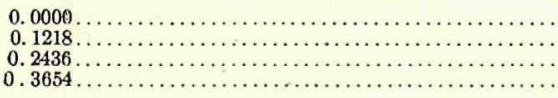 & $\begin{array}{l}27.9 \\
34.8 \\
40.8 \\
47.4\end{array}$ & $\begin{array}{l}28.1 \\
34.6 \\
41.0 \\
47.4\end{array}$ \\
\hline
\end{tabular}

Table II.-Comparison between the average yields obtained with treatments $1,2,3$ and 10 and those calculated by making use of equation (3). 
$14 t$ TILE JOIRNAL OF AGRICULTURE OF THE UNINERSITY OF P. R.

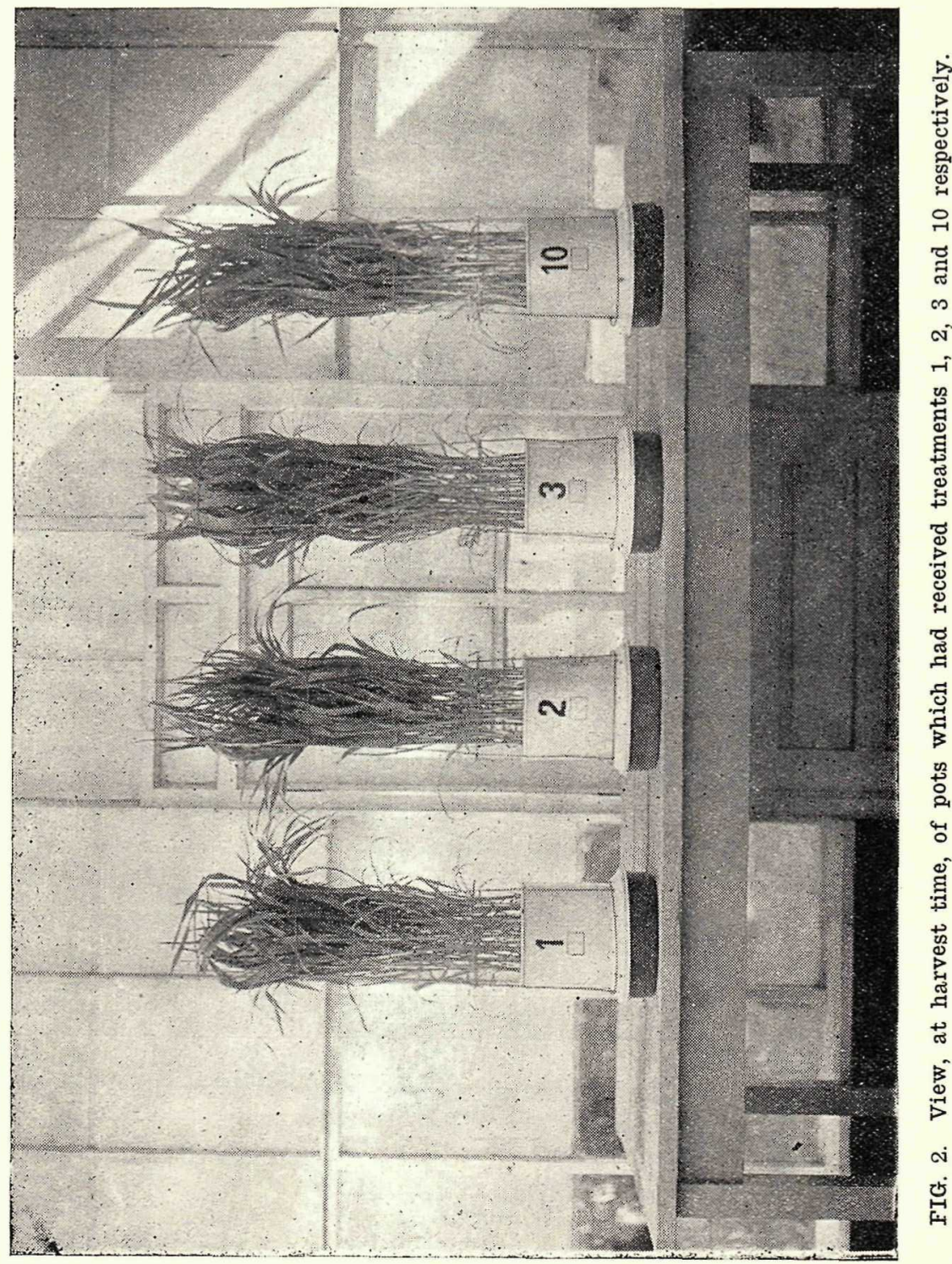




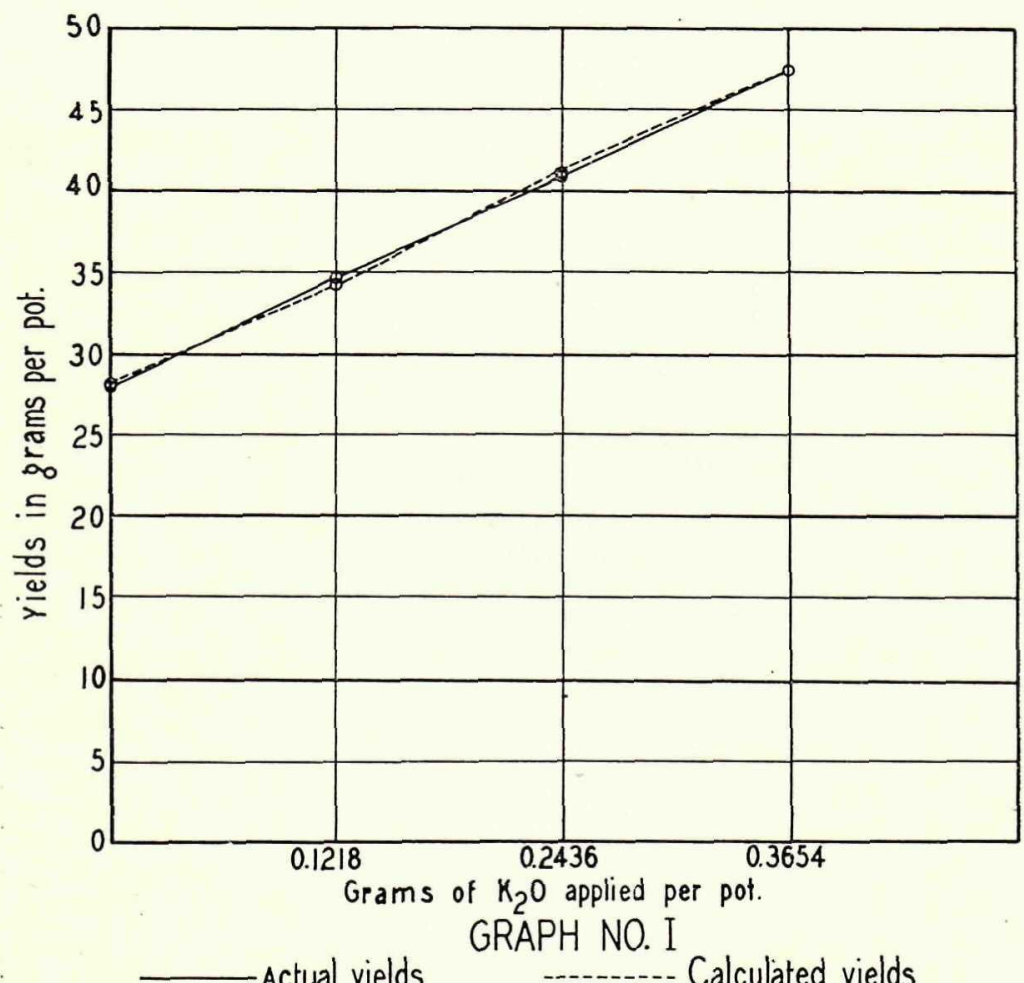

- Graph I.-Comparison between the average yields obtained with treatments $1,2,3$ and 10 and those calculated by making use of equation (3).

The good fit obtained in this case indicates that the constants of equation (3) have values which do not differ very much from the real values and that therefore the available $\mathrm{K}_{2} \mathrm{O}$ content of this soil is close to $0.5163 \mathrm{~g}$. $\mathrm{K}_{2} \mathrm{O}$ per kilogram of soil.

(b) The equation of the type of equation (2) which fits best the average results obtained with treatments $4,5,6$ and 10 is

$$
\mathrm{y}=1580.5\left(-0.88752^{0.0670+\mathrm{x}}\right) \text {. }
$$

This means that in this soil there are $0.0670 \mathrm{~g} . \mathrm{P}_{2} \mathrm{O}_{5}$ per kilogram in a form as available to the plants as the $\mathrm{P}_{2} \mathrm{O}_{5}$ in $\mathrm{Ca}\left(\mathrm{H}_{2} \mathrm{PO}_{4}\right)_{2} \mathrm{H}_{2} \mathrm{O}$ which was the salt used to furnish the $\mathrm{P}_{2} \mathrm{O}_{5}$ in this experiment. The 
fit between the actual yields obtained and those calculated by making used of equation (4) may be observed in Table III and Graph II.

\begin{tabular}{|c|c|c|}
\hline \multirow{2}{*}{ Grams $\mathrm{P}_{2} \mathrm{O}_{5}$ added per pot } & \multicolumn{2}{|c|}{$\begin{array}{l}\text { Yields (in grams of } \\
\text { dry-matter per pot) }\end{array}$} \\
\hline & Actual & Calculated \\
\hline $\begin{array}{l}0.0000 \\
0.0631 \\
0.1262 \\
0.1893 \ldots \ldots \ldots \ldots \\
\end{array}$ & $\begin{array}{l}12.0 \\
25.3 \\
35.8 \\
47.4\end{array}$ & $\begin{array}{l}12.6 \\
24.3 \\
36.0 \\
47.6\end{array}$ \\
\hline
\end{tabular}

Table III. Comparison between the average yields obtained with treatments $4,5,6$ and 10 and those calculated by making use of equation (4).

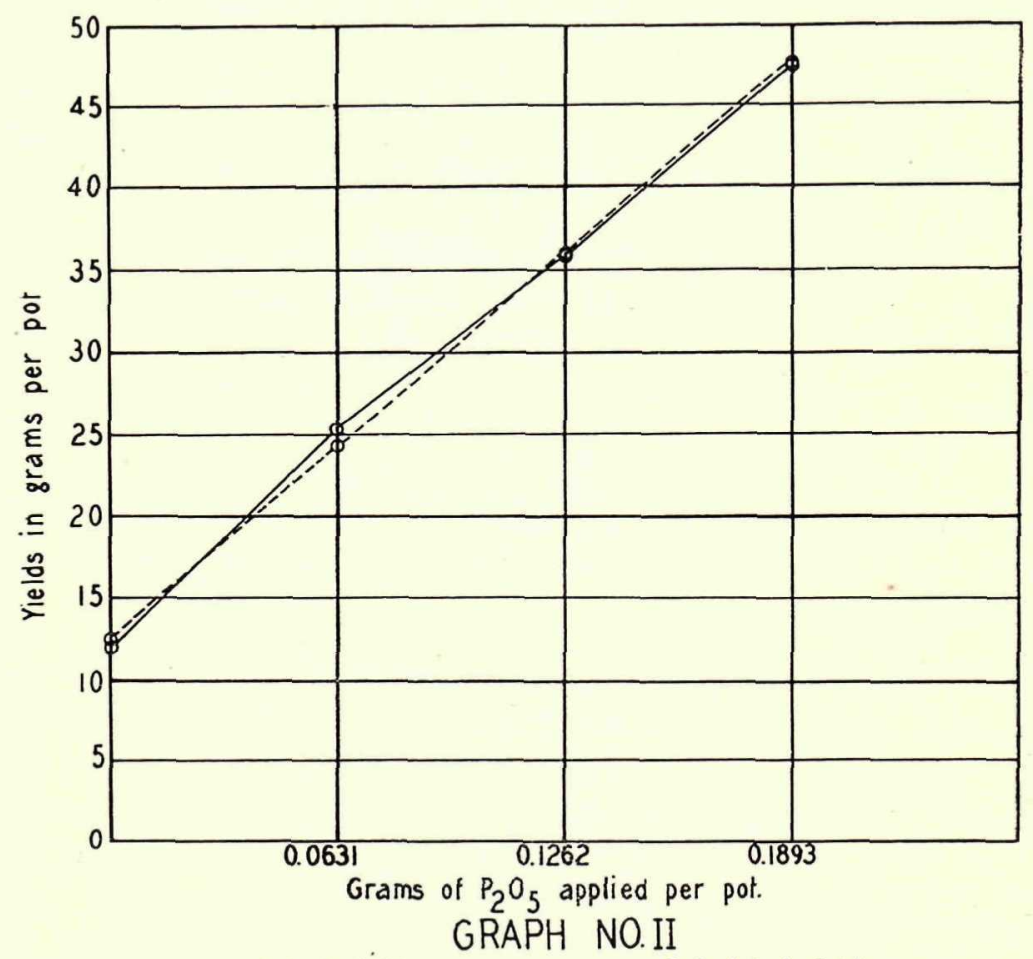

Actual yields.

Galculared yieids.

Graph II.-Comparison between the average yields obtained with treatments 4, 5, 6 and 10 and those calculated by making use of equation (4). 


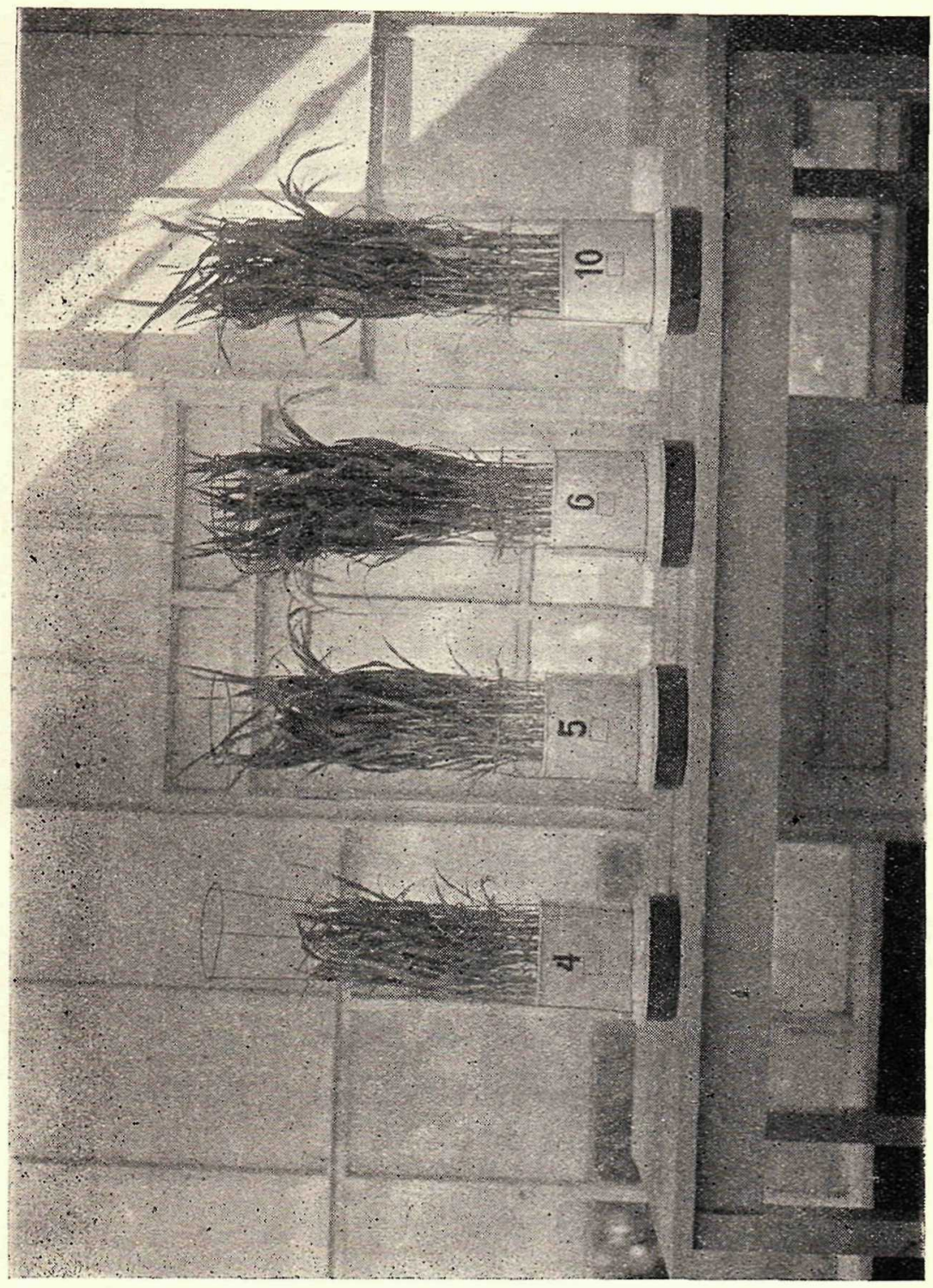

总 
The good fit obtained in this case indicates that the constants of equation (4) do not differ very much from the values of the real constants and that therefore the available $\mathrm{P}_{2} \mathrm{O}_{5}$ content of this soil is close to 0.0670 g. $\mathrm{P}_{2} \mathrm{O}_{5}$ per kilogram of soil.

(c) The equation of the type of equation (2) which fits best the average results obtained with treatments $7,8,9$ and 10 is

$$
\mathrm{y}=:=47.53\left(1-0.0313^{0.0706+\mathrm{x}}\right) \text {. }
$$

This means that in this soil there are $0.0706 \mathrm{~g} . \mathrm{NH}_{3}$ per kilogram in a form as arailable to the plants as the $\mathrm{NH}_{3}$ in $\left(\mathrm{NH}_{4}\right)_{2} \mathrm{SO}_{4}$ which was the salt used to furnish the $\mathrm{NH}_{3}$ in this experiment. The fit between the actual yields obtained and those calculated by making: use of equation (5) may be observed in Table IV and Graph III.

\begin{tabular}{|c|c|c|}
\hline \multirow[b]{2}{*}{ Grams $\mathrm{NH}_{3}$ added per pot } & \multicolumn{2}{|c|}{$\begin{array}{l}\text { Yields (in grams of } \\
\text { dry-matter per pot }\end{array}$} \\
\hline & Actual & Calculated \\
\hline 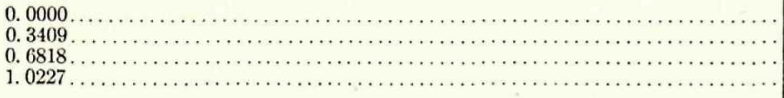 & $\begin{array}{l}10.3 \\
36.8 \\
42.5 \\
47.4\end{array}$ & $\begin{array}{l}\text { 10. } 3 \\
\text { 36. } 1 \\
\text { 44. } 0 \\
\text { 46. } 5\end{array}$ \\
\hline
\end{tabular}

Table IV.-Comparison between the average yields obtained with: treatments $7,8,9$ and 10 and those calculated by making use of equation (5).

The good fit obtained in this case indicates that the constants of equation (5) have values which do not differ very much from their real values and that therefore the available $\mathrm{NH}_{3}$ content of this soir is close to $0.0706 \mathrm{~g}$. $\mathrm{NH}_{3}$ per kilogram of soil. 


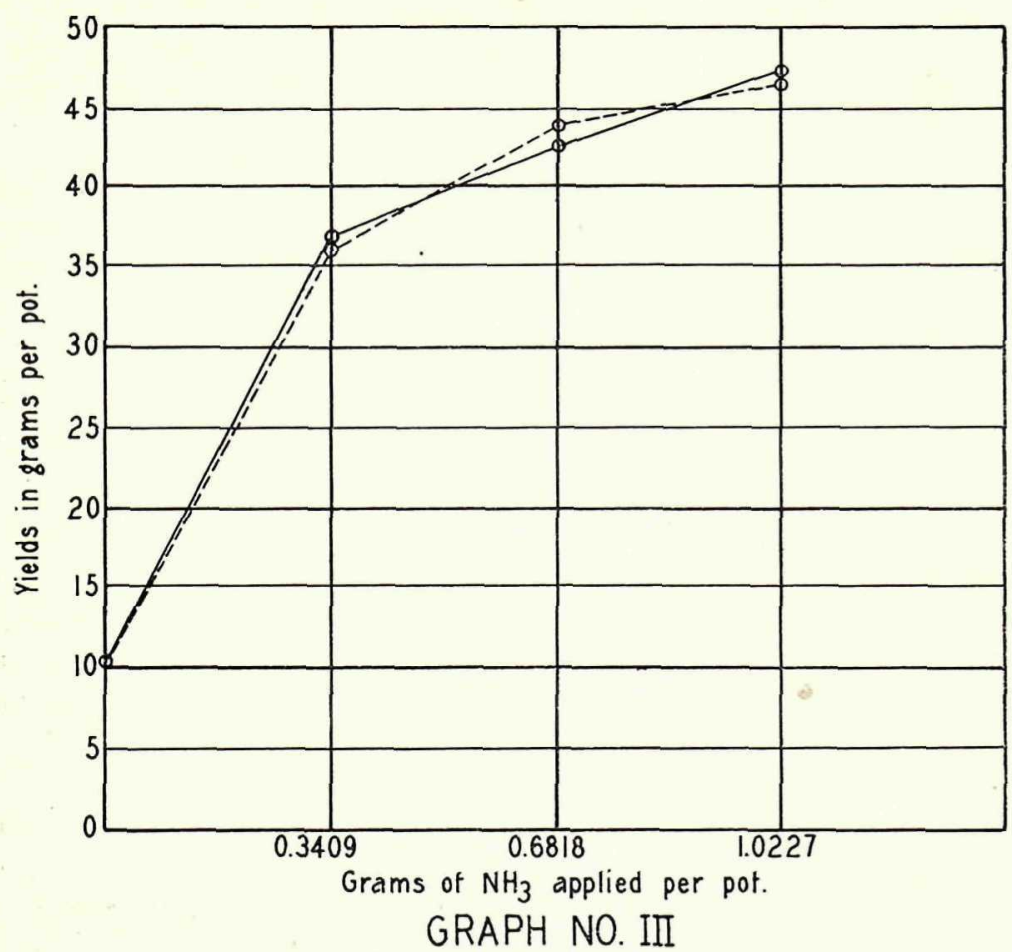

Actual yields ------ Calculared yields

Graph III.-Comparison between the average yields obtained with treatments $7,8,9$ and 10 and those calculated by making use of equation (5). 
150 THE JOURNAL OF AGRICULTURE OF THE UNIVERSITY OF P. R.

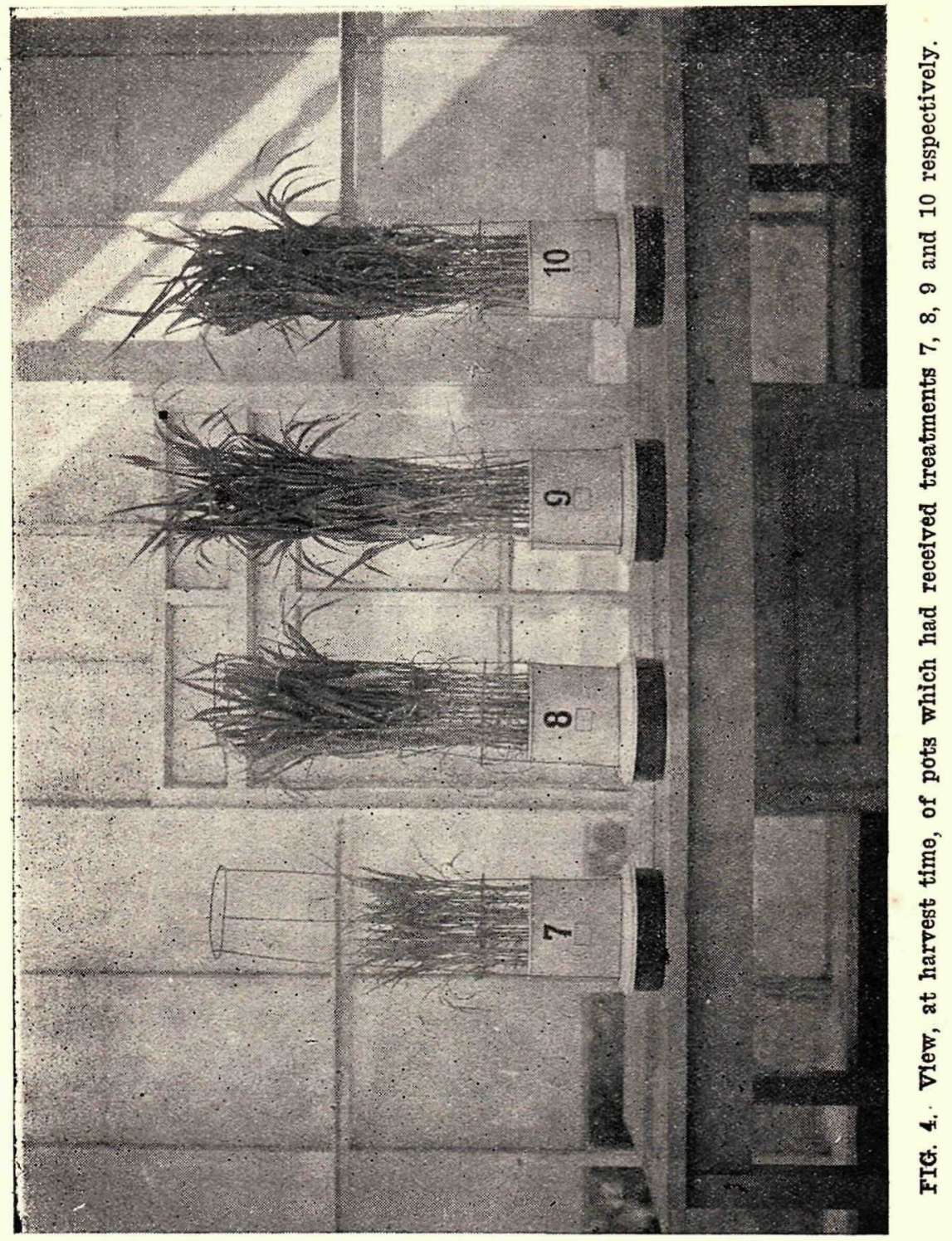


(d.) Now, since according to Mitscherlich, the effect factors corresponding to the different nutritive elements are constant, it should be possible to write out a general equation relating the plant yields with the initial concentrations of these three nutrients. The general equation is of the following type:

$$
\mathrm{y}=\mathrm{A}\left(1-\mathrm{R}_{1} \mathrm{~b}_{1}+\mathrm{x}_{1}\right)\left(1-\mathrm{R}_{2} \mathrm{~b}_{2}+\mathrm{x}_{2}\right)\left(1-\mathrm{R}_{3} \mathrm{~b}_{3}+\mathrm{x}_{3}\right)
$$

and in this particular case the calculated general equation is $\mathrm{y}=30210.2\left(1-0.0313^{0.0706+x_{n}}\right)\left(1-0.88752^{0.0670+x_{p}}\right)\left(1-0.94005^{0.5163+x_{k}}\right)(7)$

If Mitscherlich's assertion regarding the constancy of the effect factors were true, it should be possible to calculate with this equation the yields which would be produced with any known initial concentrations of all three plant nutrients. Treatments 11 and 12 were included in this experiment with the purpose of providing such a check. In Table V and Graph IV may be observed the fit between the actual yields obiained with treatments 11 and 12 and those calculated by making use of equation (7).

\begin{tabular}{|c|c|c|}
\hline \multirow{2}{*}{ Nutrients added } & & $\begin{array}{l}\text { Yields (in grams of } \\
\text { dry-matter per pot) }\end{array}$ \\
\hline & & Calculated \\
\hline $\begin{array}{l}0.3409 \text { g. } \mathrm{NH}_{3} ; 0.0631 \text { g. } \mathrm{P}_{2} \mathrm{O}_{5} ; 0.1218 \text { g. } \mathrm{K}_{2} \mathrm{O} . \\
0.6818 \text { g. } \mathrm{NH}_{3} ; 0.1262 \text { g. } \mathrm{P}_{2} \mathrm{O}_{5} ; 0.2436 \text { g. } \mathrm{K}_{2} \mathrm{O} .\end{array}$ & 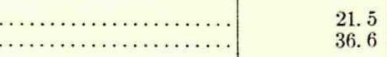 & $\begin{array}{l}13.7 \\
29.2\end{array}$ \\
\hline
\end{tabular}

Table V.-Comparison between the average yields obtained with treatments 11 and 12 and those calculated by making use of equation $(7)$. 


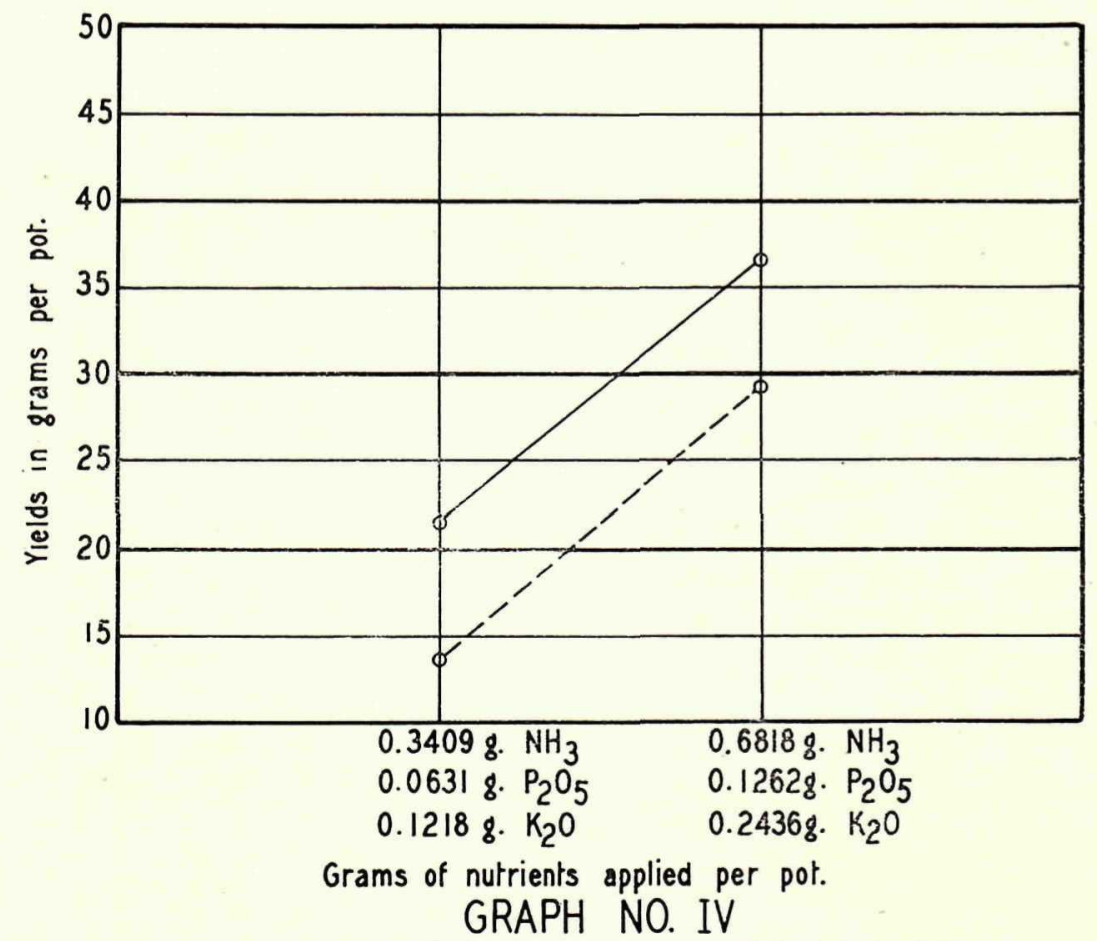

Actual yields. - - - Calculared yields.

Graph IV.-Comparison between the average yields obtained with treatments 11 and 12 and those calculated by making use of equation $(7)$.

The poor fit obtained in this case indicates that equation (7) cannot be validly used for the calculation of yields produced under the conditions of the pots with treatments 11 and 12 . This lack of agreement between the actual yields and those calculated by means of this equation is against Mitscherlich's affirmation with regard to the constancy of the effect factors.

\section{Field Experiment in Vega B.ja Silty Cl.iy}

This experiment was implanted on field 1D of the Station farm. The field was divided and the fertilizer treatments applied according to diagram No. 1 . The manured plots, being 21.75 feet in length by 14.5 feet in width, were 1/138 acre in area. The $\mathrm{NH}_{3}$ was applied as 25 per cent sulphate of ammonia, the $\mathrm{P}_{2} \mathrm{O}_{5}$ as 20 per cent superphosphate of lime and the $\mathrm{K}_{2} \mathrm{O}$ as 50 per cent sulphate of potash. 


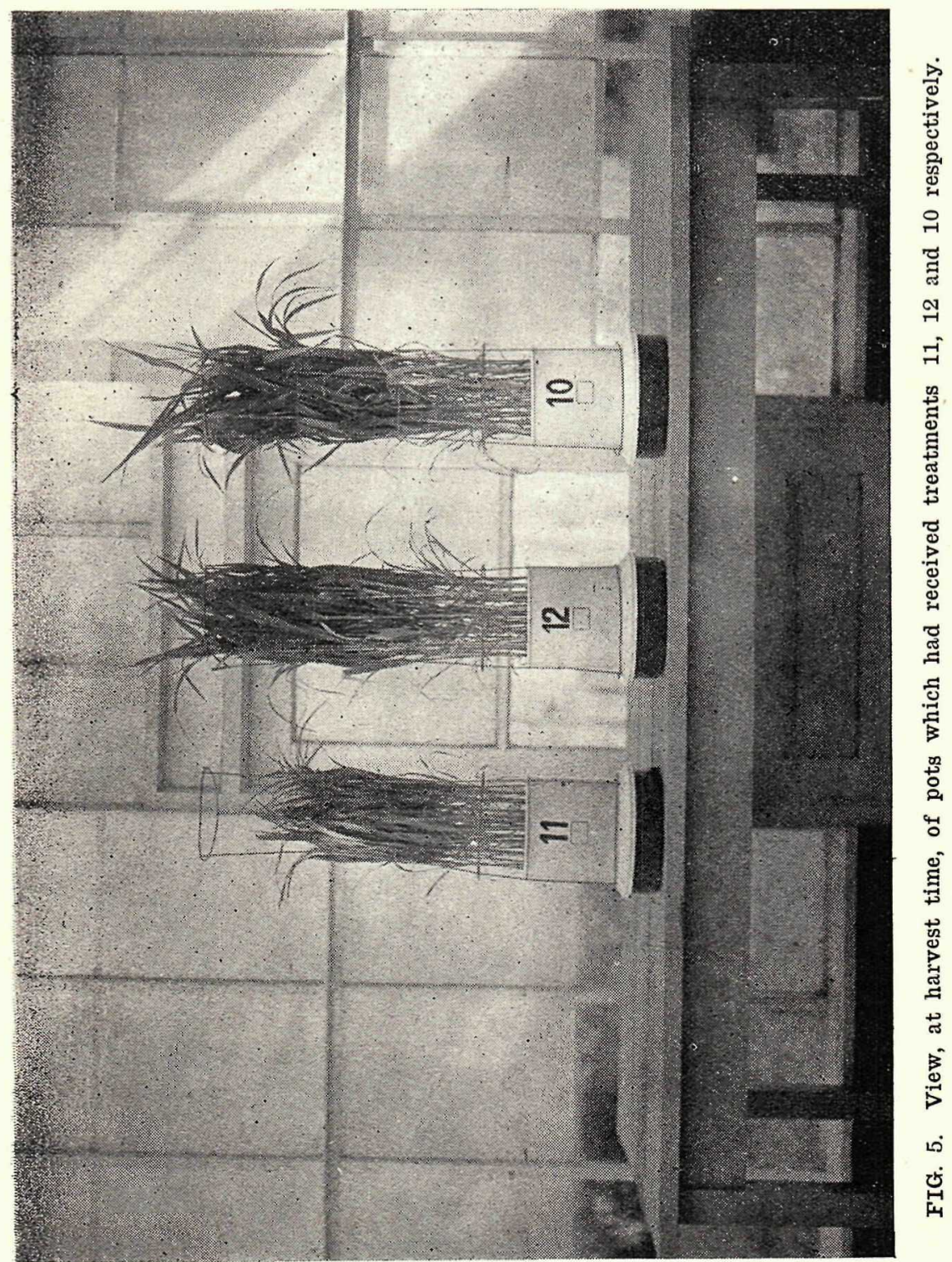


-The weighed salts corresponding to each plot were broadcasted uniformly over the whole surface of the plot. The treatments applied are described in Table VI.

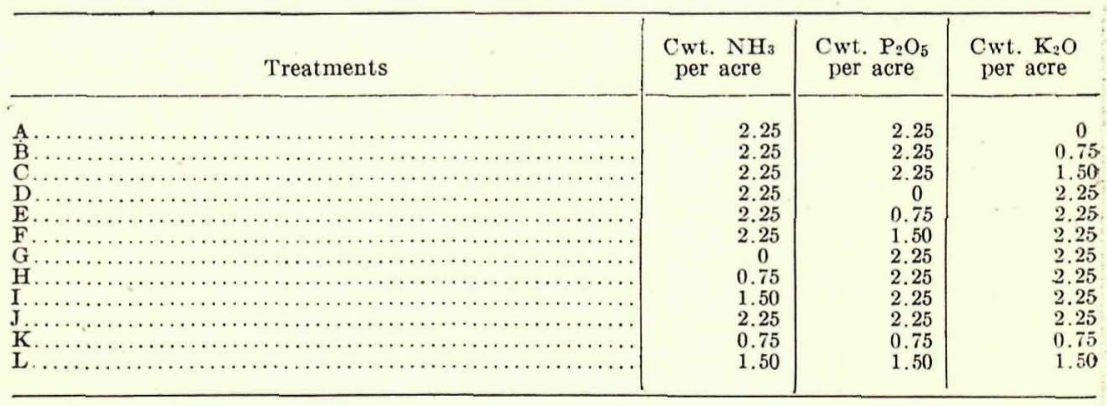

Table VI.-Treatments applied in the field experiment.

Fertilizer applications were made on January 10 and 11, 1937. The field was planted several times to Hegari Sorghum in rows 34.8 inches apart, the holes in each row being at distances of 1 foot from the adjacent ones. Three seeds were planted in each hole, there being 6 rows in each plot. Dne however to the repeated failures in obtaining the proper germination of the seeds, it was finally decided to plant the field to Sulan grass. The Hegari Sorghum seeds had a very high germination percentage but field $1 \mathrm{D}$ was infested with large numbers of ants and as soon as the seed shells were softened, the ants destroyed the seed almost completely. The Sudan grass, planted on May 6, 1937 and replanted on June 6, 1937 in the places where no seeds had germinated, gave a very good stand in all plots. The experimental field was watered almost daily for two or three weeks to insure a good stand. On Angust 23-4, 1937, the crop in each plot was harvested and weighed. Diagram No. I shows the distribution of the treatments on the experimental field and the yields in pounds per plot. 


\begin{tabular}{|c|c|c|c|c|c|c|c|c|c|c|c|}
\hline $\begin{array}{c}8-\mathrm{H} \\
104.5\end{array}$ & $\begin{array}{l}8-C \\
115.8\end{array}$ & $\begin{array}{l}8-J \\
116.4\end{array}$ & \begin{tabular}{|l|}
$8-F$ \\
114.2
\end{tabular} & \begin{tabular}{|l|}
$8-G$ \\
87.1
\end{tabular} & \begin{tabular}{|l|}
$8-D$ \\
74.3
\end{tabular} & \begin{tabular}{|c|}
$8-\mathrm{I}$ \\
105.5
\end{tabular} & $\begin{array}{c}8-B \\
114.9\end{array}$ & $\begin{array}{l}8-K \\
95.4\end{array}$ & $\begin{array}{c}8-L \\
100.8\end{array}$ & \begin{tabular}{|l|}
$8-\mathrm{A}$ \\
113.7
\end{tabular} & \begin{tabular}{|l|}
$8-E$ \\
80.7
\end{tabular} \\
\hline $7-E$ & $7-K$ & $\bar{G}$ & $7-\mathrm{H}$ & $7-C$ & $B$ & $7-L$ & $-F$ & $A$ & 7-D & $7-J$ & $7-I$ \\
\hline 95.0 & 74.4 & 72.2 & 86.2 & 90.2 & 112.3 & 89.6 & 91.1 & 101.0 & 56.5 & 97.7 & 95.5 \\
\hline $6-B$ & $6-\mathrm{F}$ & $6-D$ & $6-L$ & $6-I$ & $6-A$ & $-J$ & $6-G$ & $6-E$ & $6-K$ & $6-\mathrm{H}$ & $6-C$ \\
\hline 103.9 & 94.5 & 86.0 & 102.1 & 114.9 & 114.5 & 114.2 & 72.8 & 61.6 & 67.9 & 91.3 & 105.4 \\
\hline $\begin{array}{l}5-L \\
88.5\end{array}$ & $\begin{array}{l}5-A \\
98.4\end{array}$ & $\begin{array}{l}5-I \\
96.1\end{array}$ & $\begin{array}{l}5-J \\
113.5\end{array}$ & $\begin{array}{c}5-E \\
103.7\end{array}$ & & $\begin{array}{l}5-C \\
116.1\end{array}$ & $\begin{array}{l}5-D \\
72.5\end{array}$ & $\begin{array}{ll}5-\mathrm{H} \\
74.1\end{array}$ & \begin{tabular}{|l|}
$5-\mathrm{B}$ \\
95.7
\end{tabular} & $\begin{array}{l}5-F \\
97.5\end{array}$ & $\begin{array}{l}5-G \\
77.4\end{array}$ \\
\hline 4-I & $4-E$ & $4-K$ & $4-B$ & $4-\mathrm{H}$ & $4-L$ & $-F$ & $4-J$ & $4-C$ & $4-G$ & $4-D$ & $4-A$ \\
\hline 118.9 & 96.3 & 87.7 & 115.8 & 95.4 & 123.1 & 125.5 & 117.6 & 114.7 & 93.7 & 69.7 & 129.1 \\
\hline $\begin{array}{c}3-F \\
102.4\end{array}$ & $\begin{array}{l}3-J \\
120.5\end{array}$ & $\begin{array}{l}3-\mathrm{H} \\
81.2\end{array}$ & $\begin{array}{l}3-C \\
99.0\end{array}$ & $\begin{array}{l}3-A \\
92.0\end{array}$ & $\begin{array}{l}3-G \\
74.9\end{array}$ & \begin{tabular}{|l|}
$3-D$ \\
87.6
\end{tabular} & $\begin{array}{l}3-K \\
93.2\end{array}$ & $\begin{array}{c}3-L \\
117.2\end{array}$ & $\begin{array}{c}3-E \\
118.2\end{array}$ & $\begin{array}{c}3-I \\
129.7\end{array}$ & \begin{tabular}{|c|}
$3-B$ \\
126.6
\end{tabular} \\
\hline $2-D$ & $2-G$ & $2-L$ & $2-k$ & $2-J$ & $2-I$ & $2-A$ & $2-E$ & $2-B$ & $2-F$ & $2-C$ & $2-H$ \\
\hline 91.4 & 68.1 & 95.2 & 71.8 & 123.2 & 122.4 & 124.9 & 122.1 & 143.2 & 119.1 & 119.4 & 108.9 \\
\hline $1-A$ & $1-B$ & $1-C$ & I-D & $1-E$ & $1-F$ & $I-G$ & $1-H$ & $1-I$ & $1-J$ & $I-K$ & 1.2 \\
\hline 115.0 & 123.9 & 122.1 & 1.9 & 112.2 & 120.1 & 86.9 & 110.4 & 126.5 & 130.2 & 107.1 & 122.5 \\
\hline
\end{tabular}

DIAGRAM NO.I

DISTRIBUTION OF TREATMENTS ON EXPERIMENTAL FIELD AND

YIELDS IN LBS. PER PLOT

The results of this field experiment have been tabulated in Table VII. 
156. THE JOURNAL OF AGRICULTURE OF THE.UNIVERSITY OF P. R.

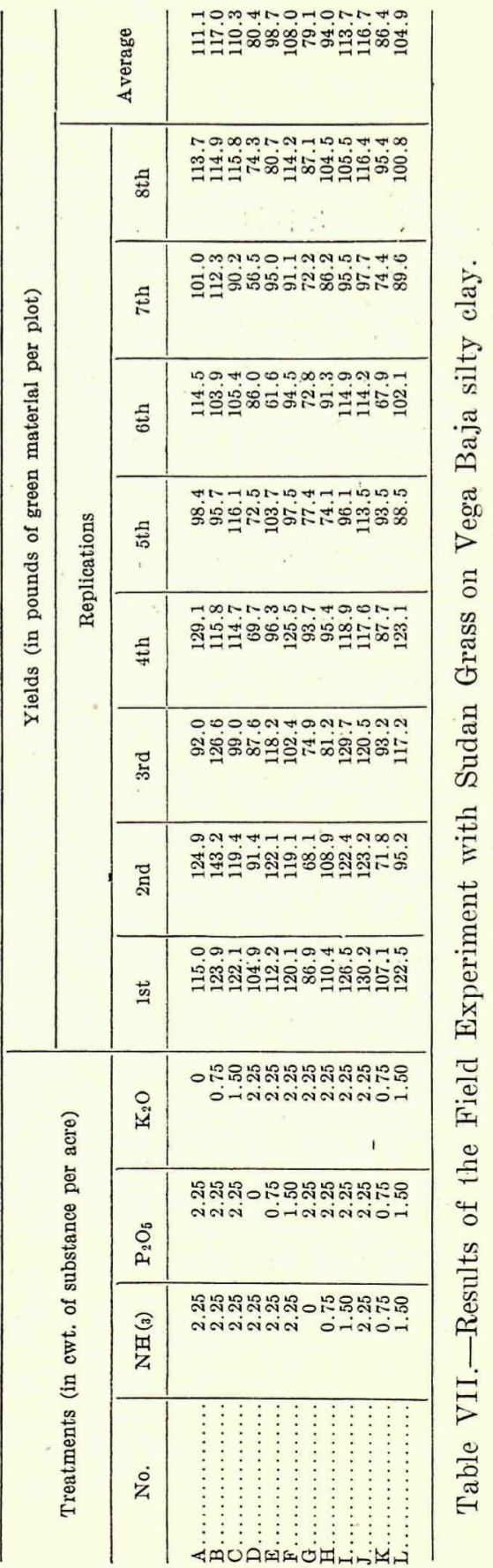


Interpretation of the Results of the F'ield Experiment: (a) The equation of the type of equation (2) which fits best the average results obtained with treatments $\mathrm{A}, \mathrm{B}, \mathrm{C}$ and $\mathrm{J}$ is

$$
\mathrm{y}=120.0\left(1-0.80518^{12.61+x}\right) \text {. }
$$

This means that in this soil there are 12.61 ewts. $\mathrm{K}_{2} \mathrm{O}$ per acre in a form as available to the plants as the $\mathrm{K}_{2} \mathrm{O}$ in sulphate of potash which was the material used to furnish the $\mathrm{K}_{2} \mathrm{O}$ in this experiment. The fit between the actual yields obtained and those calculated by making use of equation (8) may be observed in Table VIII and Graph V.

\begin{tabular}{|c|c|c|}
\hline \multirow[b]{2}{*}{ Cwts. $\mathrm{K}_{2} \mathrm{O}$ added per acre } & \multicolumn{2}{|c|}{$\begin{array}{l}\text { Yields (in pounds of } \\
\text { green material per plot) }\end{array}$} \\
\hline & Actual & Calculated \\
\hline $\begin{array}{l}0.1 \\
0.75 \\
1.50 \\
2.25 \\
2.21 \\
\end{array}$ & $\begin{array}{l}111.1 \\
117.0 \\
110.3 \\
116.7\end{array}$ & $\begin{array}{l}112.2 \\
113.4 \\
114.4 \\
115.2\end{array}$ \\
\hline
\end{tabular}

Table VIIII-Comparison between the average yields obtained with treatments $\mathrm{A}, \mathrm{B}, \mathrm{C}$ and $\mathrm{J}$ and those calculated by making use of equation (8). 


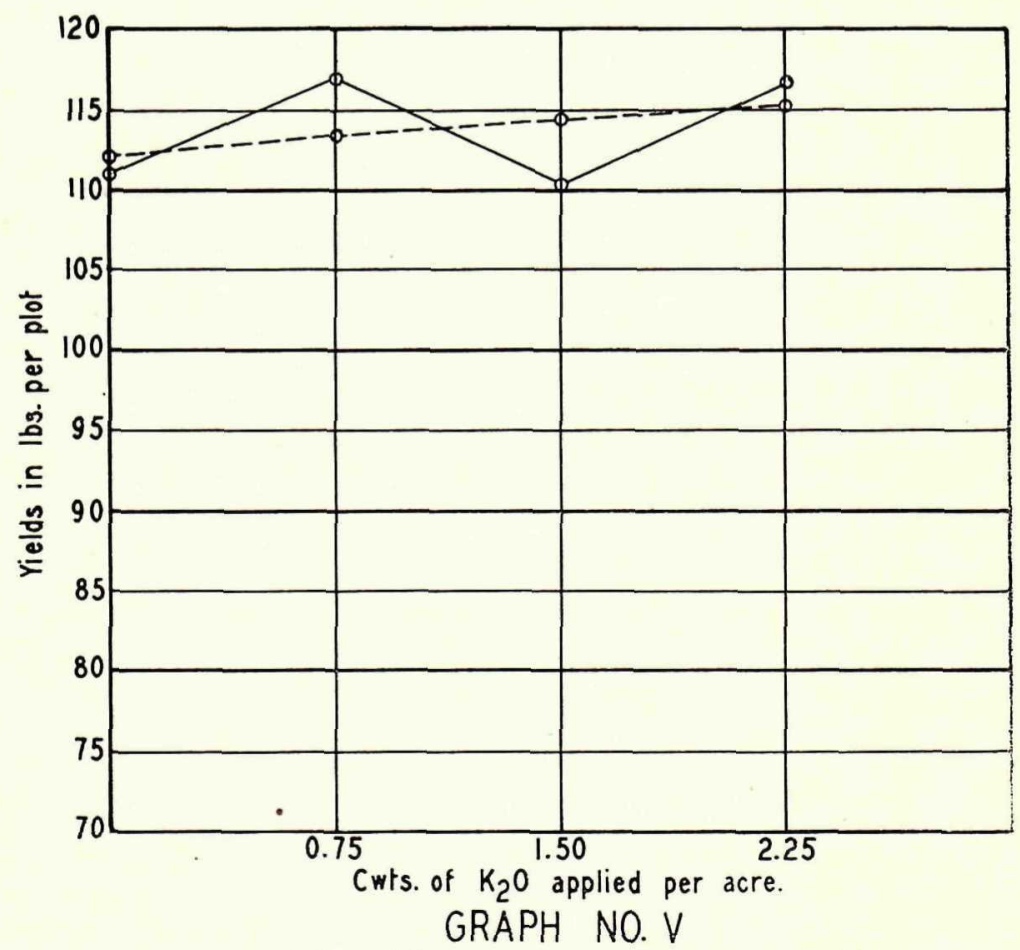

Actual yields.

Graph V.-Comparison between the average yields obtained with treatments $\mathrm{A}, \mathrm{B}, \mathrm{C}$ and $\mathrm{J}$ and those calculated by making use of equation (8).

In the pot experiment performed with this same type of soil, it was found that the surface soil of this field contained $0.5163 \mathrm{~g}$. $\mathrm{K}_{2} \mathrm{O}$ per kilogram of soil, and if it is assumed that one acre of soil weighs 2,000,000 pounds, then it would contain 1032.6 pounds $\mathrm{K}_{2} \mathrm{O}$ per acre. On the basis of this assumption, the field experiment demonsirates a presence of $1261 / 1032.6=1.22$ times the amount of potash determined as available by the pot experiment.

(b) The equation of the type of equation (2) which fits best the average results obtained with treatments D, E. F. and $J$ is

$$
\mathrm{y}=129.0\left(1-0.55385^{1.66+x}\right) \text {. }
$$

This means that in this soil there are 1.66 cwts. $\mathrm{P}_{2} \mathrm{O}_{5}$ per acre in a form as available to the plants as the $\mathrm{P}_{2} \mathrm{O}_{5}$ in superphosphate of lime which was the material used to furnish the $\mathrm{P}_{2} \mathrm{O}_{5}$ in this experiment. 
The fit between the actual yields obtained and those calculated by making use of equation (9) may be observed in Table IX and Graph VI.

\begin{tabular}{|c|c|c|}
\hline \multirow[b]{2}{*}{ Cwts. $\mathrm{P}_{2} \mathrm{O}_{5}$ added per acre } & \multicolumn{2}{|c|}{$\begin{array}{l}\text { Yields (in pounds of } \\
\text { green material per plot) }\end{array}$} \\
\hline & Actual & Calculated \\
\hline 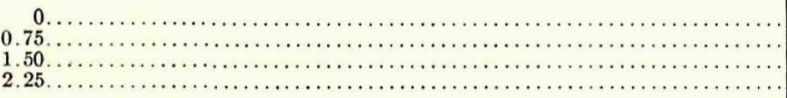 & $\begin{array}{r}80.4 \\
98.7 \\
108.0 \\
116.7\end{array}$ & $\begin{array}{r}80.6 \\
97.9 \\
109.1 \\
116.2\end{array}$ \\
\hline
\end{tabular}

Table IX.-Comparison between the average yields obtained with treatments D, E. F and $\mathrm{J}$ and those calculated by making use of equation (9).

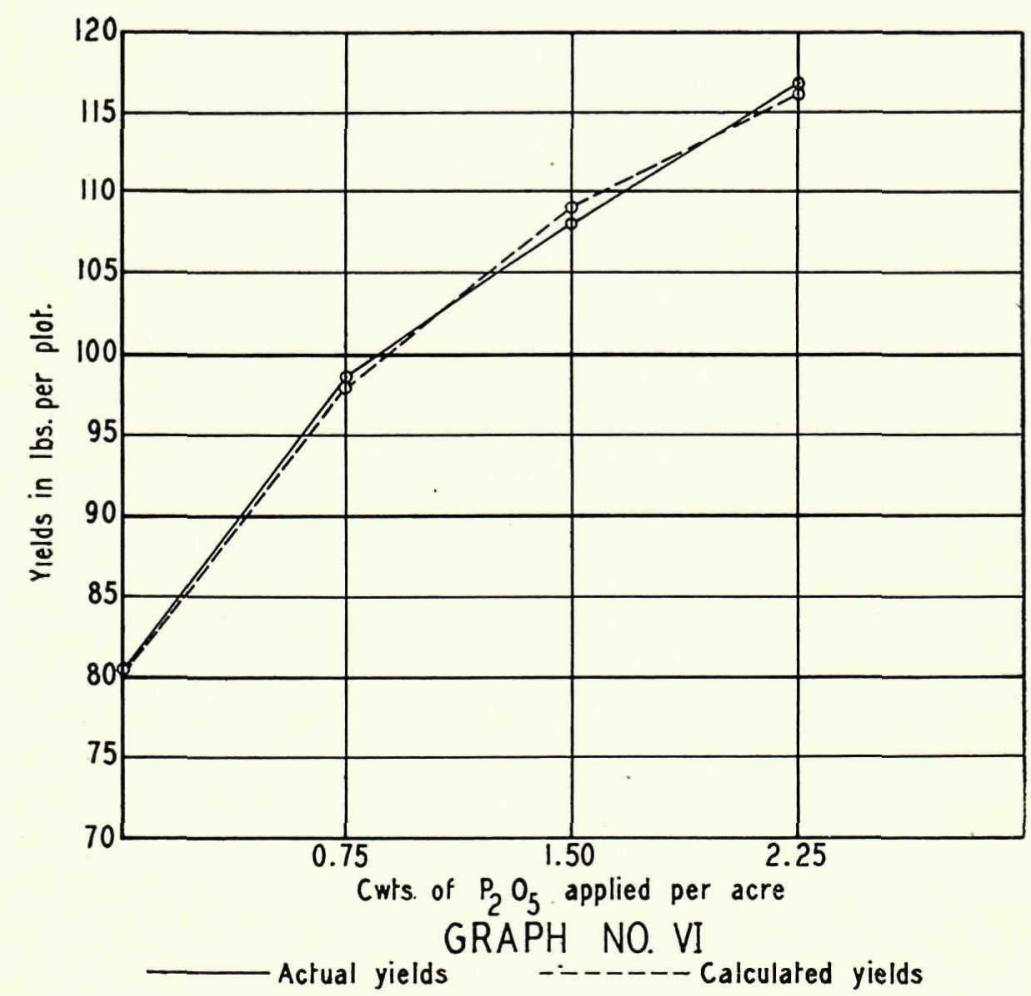

Graph VI.-Comparison between the average yields obtained with treatments D, E. F and $J$ and those calculated by making use of equation (9). 
In the pot experiment performed with this same type of soil it was found that the surface soil of this field contained $0.0670 \mathrm{~g}$. $\mathrm{P}_{2} \mathrm{O}_{5}$ per kilogram of soil, and if it is assumed that one acre of soil weighs 2,000,000 pounds, then it would contain 134 pounds $\mathrm{P}_{2} \mathrm{O}_{5}$ per acre. On the basis of this assumption, the field experiment demonstrates a presence of $166 / 134=1.24$ times the amount of $\mathrm{P}_{2} \mathrm{O}_{5}$ determined by the pot experiment. This figure compares favorably with the previous one of 1.22 obtained in the case of $\mathrm{K}_{2} \mathrm{O}$ as the variable factor. The ratio of the amounts of $\mathrm{P}_{2} \mathrm{O}_{5}$ and $\mathrm{K}_{2} \mathrm{O}$ determined by the pot experiment is practically equal to the ratio of the amounts of $\mathrm{P}_{2} \mathrm{O}_{5}$ and $\mathrm{K}_{2} \mathrm{O}$ determined by the field experiment. This may be considered a good check with regard to the accuracy of this kind of pot experiments.

(c) The equation of the type of equation (2) which fits best the average results obtained with treatments $G, H, I$ and $J$ is

$$
y=136.6\left(1-0.5968^{1.65+x}\right) \text {. }
$$

This means that in this soil there are 1.65 cwts. $\mathrm{NH}_{3}$ per acre in a form as available to the plants as the $\mathrm{NH}_{3}$ in sulphate of ammonia which was the material used to furnish the $\mathrm{NH}_{3}$ in this experiment. The fit between the actual yields obtained and those calculated by making use of equation (10) may be observed in Table $\mathrm{X}$ and Graph VII.

\begin{tabular}{|c|c|c|}
\hline \multirow[b]{2}{*}{ Cwts. $\mathrm{NH}_{3}$ added per acre } & \multicolumn{2}{|c|}{$\begin{array}{l}\text { Yields (in pounds of } \\
\text { green material per plot) }\end{array}$} \\
\hline & Actual & Calculated \\
\hline $\begin{array}{l}0 \ldots \\
0.75 \ldots \\
1.50 \ldots \\
2.25 \ldots\end{array}$ & $\begin{array}{r}79.1 \\
94.0 \\
113.7 \\
116.7\end{array}$ & $\begin{array}{r}78.3 \\
97.0 \\
109.0 \\
117.9\end{array}$ \\
\hline
\end{tabular}

Table X.-Comparison between the average yields obtained with the treatments $\mathrm{G}, \mathrm{H}, \mathrm{I}$ and $\mathrm{J}$ and those calculated by making use of equation (10). 


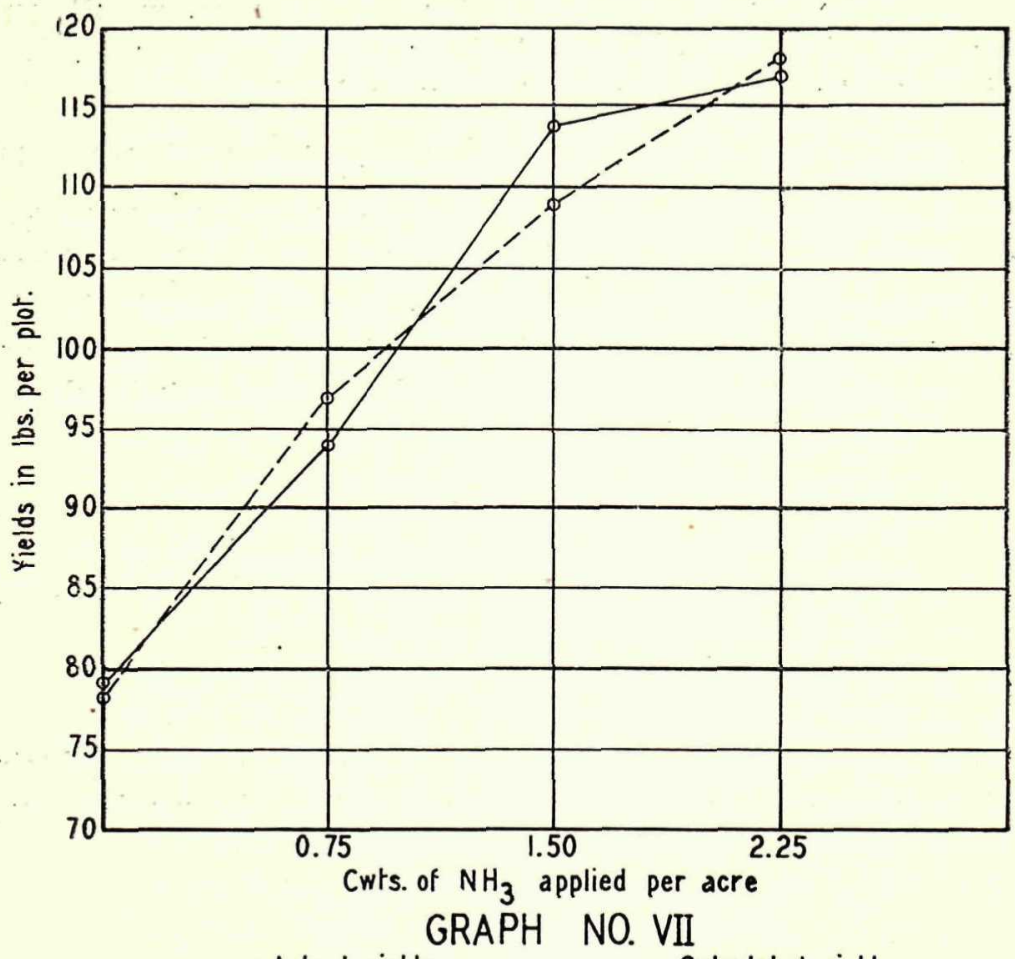

Actual yields

Calculated yields

Graph VII.-Comparison between the average yields obtained with the treatments $\mathrm{G}, \mathrm{H}, \mathrm{I}$ and $\mathrm{J}$ and those calculated by making use of equation (10).

In the pot experiment performed with this same type of soil, it was found that the surface soil of this field contained $0.0706 \mathrm{~g}$. $\mathrm{NH}_{3}$ per kilogram of soil, and if it is assumed that one acre of soil weighs 2,000,000 pounds, then it would contain 141.2 pounds $\mathrm{NH}_{3}$ per acre. On the basis of this assumption, the field experiment demonstrates a presence of $165 / 141.2=1.17$ times the amount of $\mathrm{NH}_{3}$ determined by the pot experiment. This figure is of the same order as the two previous ones found with $\mathrm{K}_{2} \mathrm{O}$ and $\mathrm{P}_{2} \mathrm{O}_{5}$ as nutrients in variable amounts and it seems as if it might be concluded, in the light of this evidence, that pot experiments of this type may be used to determine with fair accuracy the relative available amounts of the three principal nutrients, i. e., nitrogen, phosphoric acid, and potash. 
(d) If the general equation of the type of equation (6) corresponding to this experiment is calculated from the equations (8), (9) and (10), the following general equation is obtained:

$$
y=153.6\left(1-0.568^{1.65+x_{n}}\right)\left(1-0.55385^{1.66+x_{p}}\right)\left(1-0.80518^{12.61+x_{k}}\right) .
$$

Calculating by means of equation (11) the yields which should have been produced by treatments $\mathrm{K}$ and $\mathrm{L}$ of the field experiment, and comparing these calculated values with the actual yields obtained in said experiment, it will be found that in this case there is a very poor fit between these results. This poor fit may be observed in Table XI and Graph VIII.

\begin{tabular}{|c|c|c|}
\hline \multirow{2}{*}{ Nutrients added per acre } & \multicolumn{2}{|c|}{$\begin{array}{l}\text { Yields (in pounds of } \\
\text { green material per plot) }\end{array}$} \\
\hline & Actual & Calculated \\
\hline 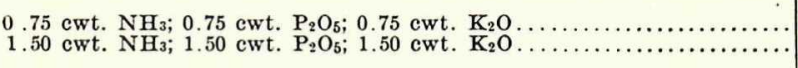 & $\begin{array}{r}86.4 \\
104.9\end{array}$ & $\begin{array}{l}78.2 \\
98.8\end{array}$ \\
\hline
\end{tabular}

Table XI.-Comparison between the average yields obtained with treatments $\mathrm{K}$ and $\mathrm{L}$ and those calculated by making use of equation (11). 


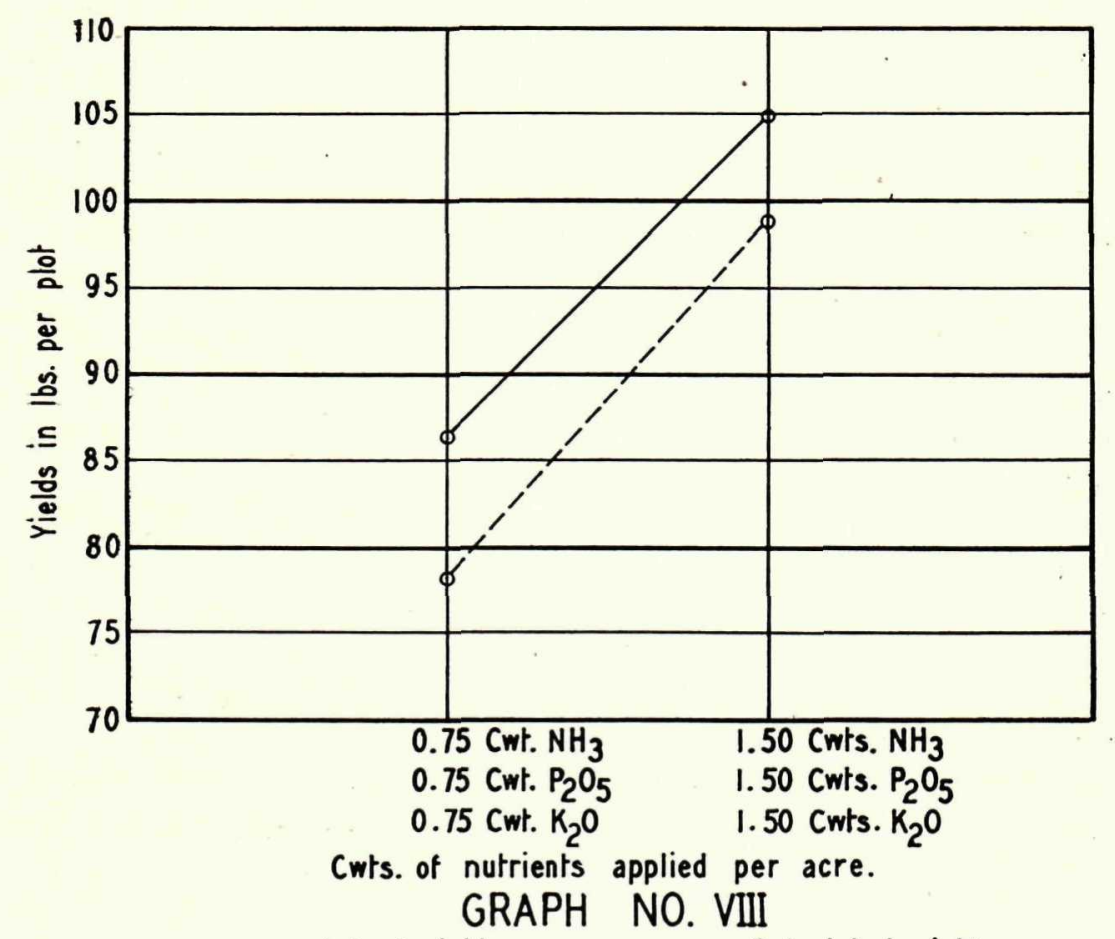

Actual yields.

Calculated yields.

Graph VIII.-Comparison between the average yields obtained with treatments $\mathrm{K}$ and $\mathrm{L}$ and those calculated by making use of equation (11).

This behaviour is analogous to the one observed in the case of the pot experiment and it corroborates a conclusion which might have been drawn from those results, in fact, that the general equation calculated for a crop growing in a soil under certain fertilizer concentrations is not applicable to other conditions. This same behaviour was noticed by the late W. J. Spillman on studying the results of a tobacco fertilizer experiment conducted by W. W. Garner and his associates at Georgia. The explanation for these discrepancies offered by Spillman might be accepted for said experiment but in our case, where the conditions claimed to produce those effecis were not present, no explanations of this sort are possible to maintain the general applicability of such an equation. If this is so, then, the 4-treatment procedure recommended by Mitcherlich, based on the applicability of this general equation and with fixed values for the effect factors, shonld not give reliable results. 
The conclusion arrived at, therefore, is that the 7-treatment tests should be preferred to the 4-treatment ones recommended by Mitscherlich, for although they are more elaborate and costly than the 4-treatment ones, yet their accuracy more than offsets the disadvantages mentioned.

Procedure Followed at Present for the Determinarion of the Nutrient Contents of a Soll by Means of Pot Tests

Partial samples to the desired depth are taken at several places in the field representing the soil type to be studied. These soil samples are air dried, sieved through a 0.25 inch circular hole sieve and well mixed.

The proportion of soil to Corozos sand in the soil-sand mixture to be used in the pot tests is determined from the texture of the soil sample. For example, with clays or silty clays 2 kilos of soil are mixed with 4 kilos of Corozos sand, with sandy loams 4 kilos of soil are mixed with 2 kilos of Corozos sand, etc., to make up the 6 kilos for each pot.

The soil and sand are mixed in an oil cloth with the proper amounts of the salts which are used to furnish the nutritive materials. The following seven treatments are given by quadruplicate to each soilsand mixture:

$$
\begin{aligned}
& \text { 1-1. } 000 \text { g. } \mathrm{NH}_{3} ; 1.000 \text { g. } \mathrm{P}_{2} \mathrm{O}_{5} . \\
& 2 \text {-1.000 g. } \mathrm{NH}_{3} ; 1.000 \text { g. } \mathrm{P}_{2} \mathrm{O}_{5} ; 0.500 \text { g. } \mathrm{K}_{2} \mathrm{O} . \\
& 3 \text {-1. } 000 \text { g. } \mathrm{NH}_{3} ; 1.000 \text { g. } \mathrm{K}_{2} \mathrm{O} . \\
& 4-1.000 \text { g. } \mathrm{NH}_{3} ; 0.500 \text { g. } \mathrm{P}_{2} \mathrm{O}_{5} ; 1.000 \text { g. } \mathrm{K}_{2} \mathrm{O} . \\
& 5-1.000 \text { g. } \mathrm{P}_{2} \mathrm{O}_{5} ; 1.000 \text { g. } \mathrm{K}_{2} \mathrm{O} . \\
& 6-0.500 \text { g. } \mathrm{NH}_{3} ; 1.000 \text { g. } \mathrm{P}_{2} \mathrm{O}_{5} ; 1.000 \text { g. } \mathrm{K}_{2} \mathrm{O} . \\
& 7-1.000 \text { g. } \mathrm{NH}_{3} ; 1.000 \text { g. } \mathrm{P}_{2} \mathrm{O}_{5} ; 1.000 \text { g. } \mathrm{K}_{2} \mathrm{O} .
\end{aligned}
$$

Of the 28 pots used to study each soil: treatment 1 is given to pots Nos.. $1,8,15$ and 22 ; treatment 2 is given to pots Nos. $2,9,16$ and 23 ; treatment 3 is given to pots Nos. $3,10,17$ and 24 ; treatment 4 is given to pots Nos. $4,11,18$ and 25 ; treatment 5 is given to pots Nos. 5, 12, 19 and 26 ; treatment 6 is given to pots Nos. 6 , 13, 20 and 27; and treatment 7 is given to pots Nos. 7, 14, 21 and 28.

Once the soil, sand and salts corresponding to a given pot are well mixed, the whole mixture is transferred to the corresponding Mitscherlich's pot. Each pot is weighed and is then ready to plant.

Immediately before planting, $400 \mathrm{ml}$. of distilled water are poured in top of the soil of the pot with a sprinkler. With the Hegari Sorghum seeds now available, 40 seeds are planted in each pot with 
the idea of leaving 35 plants to grow in each pot. The seeds are halfburied, by using a small forceps. The seeds are distributed uniformly upon the whole surface of the pot. A rapid and easy way to do this distribution is to plant the first 37 seeds in the order illustrated in diagram No. 3, turning the pots around after planting seed No. 22. The other three seeds are planted to fill the largest vacant spaces remaining after the first 37 seeds are planted.

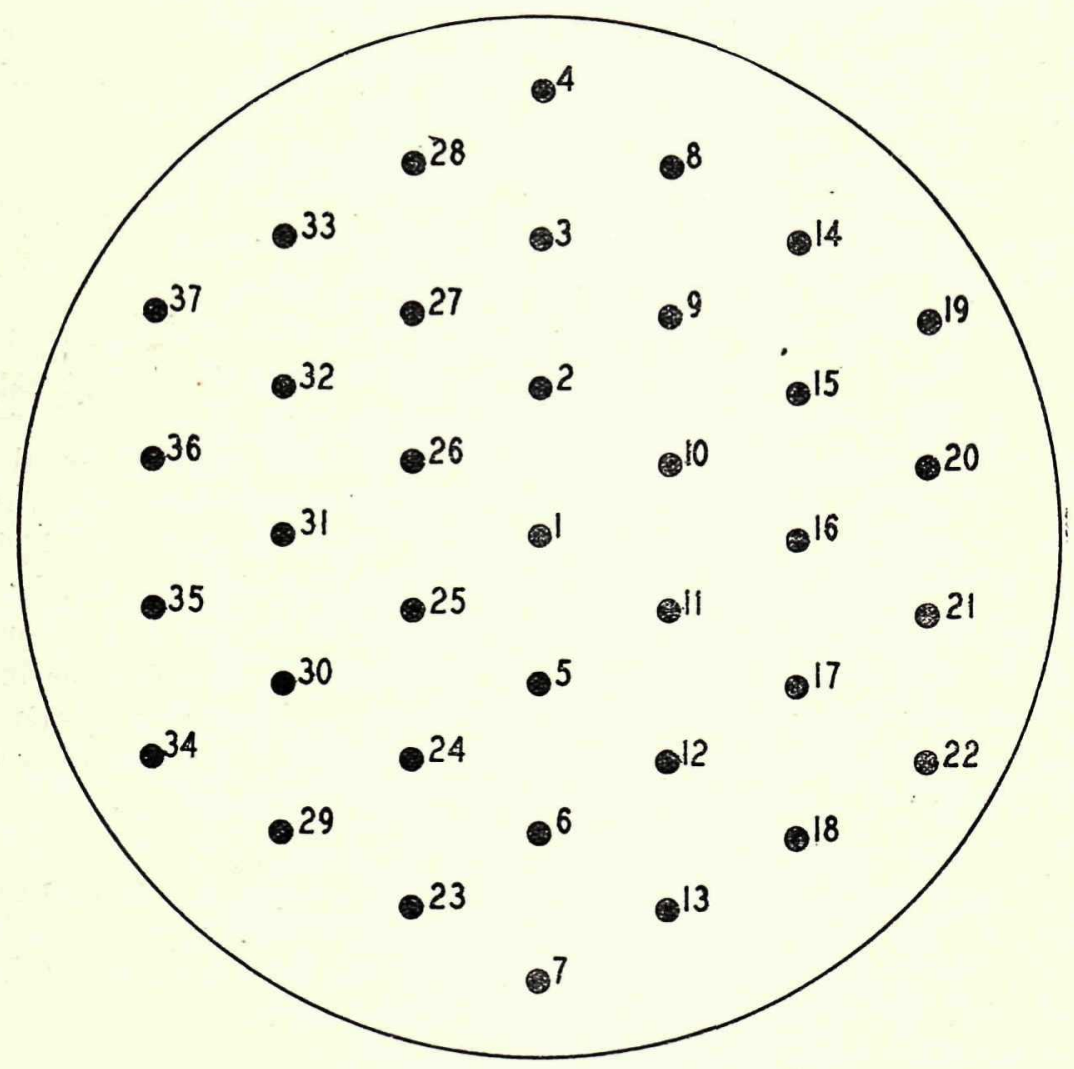

DIAGRAM NO. II

MANNER OF PLANTING SEEDS IN ORDER TO OBTAIN A UNIFORMLY SPACED DISTRIBUTION.

After the 40 seeds have been half-buried, drops of water are allowed to fall over and around the seeds in order to pack the soil against the seeds but leaving their upper part uncovered. 
The next day nearly all the seeds will have broken their shells. The seeds which have loosened themselves are half-buried again and the whole surface of the pot is moistened.

This procedure is repeated the next day, by which time the seeds will have sent their first root into the soil and their shoots will be about $1 / 2$ inch in height.

On the next day most of the plants will have already 2 leaves open and they will be about $1 \frac{1}{2}$ inches in length. The ungerminated seeds and as many plants as necessary are removed this day from each pot, leaving 35 plants in each pot. Each pot is brought with distilled water to a weight equal to its dry weight plus $800 \mathrm{~g}$.

In the succeeding days the water content of the pots is raised by increasing the weight of the pots by $200 \mathrm{~g}$. daily at first and then by smaller amounts until full water capacity is attained. The idea is to attain this full water eapcity as soon as possible.

After this stage has been reached the first thing in the morning to be done is to see which pots have percolated water to the pan below and which ones have not. The pots which have percolated water are brought with distilled water to the same weight as on the previous day, after pouring on the pot the percolated solution. The pots which have not percolated water are brought to a weight which is $10 \mathrm{~g}$. larger than the corresponding weights of the previous day. However, if after thus increasing the weight of one pot by $10 \mathrm{~g}$. on a day it is found on the next day that no water percolates, the increase in weight on the next day (and succeeding ones if necessary) will be by $20 \mathrm{~g}$. This watering procedure is continued until harvest time; in our case, until the plants are about to head.

At harvest time all the material above the soil in each pot is cut into pieces of about 1 inch in length and placed in a tared wire basket. These baskets are placed on a constant temperature electric oven and kept at a temperature of about $115^{\circ} \mathrm{C}$. until constant weight is attained. It is usually found that this condition is attained on allowing the oven to stay lighted overnight.

The baskets are weighed on a torsion balance to the nearest 0.1 gram immediately upon removing from the oven, the procedure being to remove one tray and weigh it before removing the next.

The calculations necessary to do the interpretation of one of these experiments are presented below. This experiment was performed with Río Piedras clay, a very acid type of soil $(\mathrm{pH}-4.39)$ in which a previous experiment done without $\mathrm{CaCO}_{3}$ applications had failed due to the extreme acidity of this soil. For this reason, $\mathrm{CaCO}_{3}$ as a rariable factor was also introduced in this experiment, making a 
total of 9 treatments instead of the standard number of 7 treatments. The treatments and yields obtained are found in Table XII. In this case 2 kilos of soil were mixed with 4 kilos of Corozos sand.

\begin{tabular}{|c|c|c|c|c|c|c|}
\hline \multirow[b]{3}{*}{ No. } & Treatments & \multicolumn{5}{|c|}{ Yields (in grams per plot) } \\
\hline & \multirow{2}{*}{ Nutrients added per pot } & \multicolumn{4}{|c|}{ Replications } & \multirow[b]{2}{*}{ Average } \\
\hline & & 1st & 2nd & 3rd & 4 th & \\
\hline . & \multirow{8}{*}{ 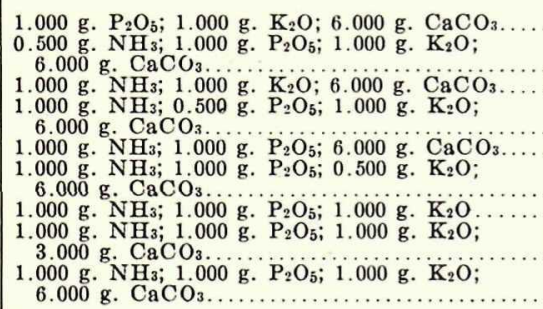 } & 19.0 & 18.2 & 17.5 & 17.8 & 18.125 \\
\hline & & $\begin{array}{r}34.7 \\
7.1\end{array}$ & $\begin{array}{r}33.6 \\
7.1\end{array}$ & $\begin{array}{r}33.6 \\
7.7\end{array}$ & $\begin{array}{r}33.6 \\
7.2\end{array}$ & $\begin{array}{r}33.875 \\
7.275\end{array}$ \\
\hline 4 & & 30.5 & 32.4 & 29.9 & 30.0 & 30.700 \\
\hline $\begin{array}{l}5 \ldots \ldots \\
6 \ldots \ldots\end{array}$ & & 23.3 & 22.3 & 19.8 & 22.9 & 22.075 \\
\hline & & 31.8 & 36.7 & 34.1 & 32.2 & 33.7 \\
\hline & & & & & & \\
\hline \multirow{2}{*}{$9 \ldots \ldots$} & & 30.9 & 33.6 & 31.1 & 31.8 & 31.850 \\
\hline & & 34.6 & 36.0 & 32.9 & 35.5 & 34.750 \\
\hline
\end{tabular}

TABLE XII. Results obtained in a fertilizer pot experiment with Rio Piedras clay.

The following formulas, derived from equation (2), are used to simplify the calculation processes:

$$
\begin{aligned}
& \mathrm{R}=\frac{\mathrm{y}_{3}-\mathrm{y}_{2}}{\mathrm{y}_{2}-\mathrm{y}_{1}} \\
& \mathrm{M}=\frac{\mathrm{y}_{2}-\mathrm{y}_{1}}{\mathrm{R}^{\mathrm{x}_{1}-} \mathrm{R}^{\mathrm{x}_{2}}} \\
& \mathrm{~A}=\mathrm{y}_{1}+\mathrm{MR}^{\mathrm{x}_{1}} \\
& \mathrm{~b}=\frac{\log \mathrm{M}-\log \mathrm{A}}{\log \mathrm{R}}
\end{aligned}
$$

To calculate the amount of available $\mathrm{NH}_{3}$ in the 2 kilos of soil used for the soil-sand mixture, the average yields of treatments 1,2 and 9 are used. Thus, expressing the $\mathrm{NH}_{3}$ aplications as units of $0.500 \mathrm{~g} . \mathrm{NH}_{3}$ to simplify the calculations.

$$
\begin{array}{ll}
\mathrm{x}_{1}=0 ; & \mathrm{y}_{1}=18.125 \\
\mathrm{x}_{2}=1: & \mathrm{y}_{2}=33.875 \\
\mathrm{x}_{3}=2 ; & \mathrm{y}_{3}=34.750
\end{array}
$$

Therefore, $\quad R=\frac{34.750-33.875}{33.875-18.125}=\frac{0.875}{15.750}=0.05556$

$$
\begin{aligned}
& \mathrm{M}=\frac{15.750}{1-0.0556}=\frac{15.750}{0.944444}=16.6765 \\
& \Lambda=18.125+16.6765=34.8 \\
& \mathrm{~b}=\frac{1.22210-1.54158}{0.74476-2}=\frac{-0.31948}{-0.25524}=0.2545 \text { units or }
\end{aligned}
$$


$0.2545\left(0.500\right.$ g. $\left.\mathrm{NH}_{3}\right)=0.1272 \mathrm{~g} . \mathrm{NH}_{3}$. Therefore, this soil contains $0.1272 \mathrm{~g} . \mathrm{NH}_{3}$ per 2 kilos of soil.

The calculation of the available amounts of the other nutrients is made in a similar way.

\section{Summari and Conclusions}

A discussion of the principles underlying the applications of Mitscherlich's equations to the determination of the nutrient contents of a soil and of the objects in view in complying with the requisites of the project under which the described studies were done have been made.

The procedure employed in performing a certain pot experiment with Mitscherlich's pots is described. A detailed interpretation of the results of that experiment has been made.

The procedures used in performing and in the interpretation of the yield data obtained from a field experiment implanted on a field with the same soil type as was used in the pot experiment have been also described. The results of both of these experiments have been compared and the conclusions set further on have been derived from the results obtained in this comparison.

Detailed instructions for making the determination of the nutrient contents of a soil by a modification of Mitscherlich's 4-treatment method are presented.

The following conclusions are derived from the experimental data presented:

1. Mitscherlich's special equation for the relation existing between the initial nutrient concentration of a single nutrient in a soil and the yield of a crop there planted is an accurate and simple one.

2. Such an equation may be used to determine with a high precision the available amount of any nutrient in a given soil.

3. Mitscherlich's general equation relating the yield of a crop with the initial concentrations of the three principal nutrients, (nitrogen, phosphoric acid and potash), does not hold.

4. Mitscherlich's 4-treatment method, based on the applicability of this latter equation, is not accurate under Puerto Rican conditions for the vegetative period of growth of a crop, that is, from the time of planting to the time of heading.

5. A modification of Mitscherlich's method, including 7 treatments and based on the applicability of the Mitscherlich's special equations for variations in the concentrations of each individual nutrient respectively, is described as now used. 


\section{ACKNOWLEDGMENTS}

The author wishes to express his profound gratitude to Mr. Fernando Chardón, Assistant Sugar-Cane Specialist, for his invaluable cooperation by drawing the graphs and diagrams with which this article has been illustrated. He also desires to make known his everlasting sympathy and appreciation to Mr. Juan Amedée Bonnet, Soils Expert, who as leader of the project under which the work outlined was done, cooperated whole-heartedly to its progress, and who had the courtesy and benevolence to aid with valuable suggestions for the correction of the galley proofs of this article.

\section{References}

1. Capó, B. G. Fertilizers and Crop Yields, (Rev. Ed.), Memoirs 1934 Annual Meeting of the Association of Sugar Cane Technologists of Puerto Rico, p. 27-54, 1935.

2. Hartung, w. J. The Mitscherlich Method of Soil Testing and Interpretation of Results. 'The Hawaiian Planters' Record, 33 (4) : 439-448, 1929.

3. Mellor, J. W. Higher Mathematies for Students of Chemistry and Physics, New Impression. Longmans, Green and Co., London, 1931.

4. Merriman, M. A Text-Book on the Method of Least Squares. 8th Rev. Ed. John Wiley and Sons, Inc., New York, 1911.

5. Mitscherlich, E. A. Die Bestimmung des Dungerbedürfnisses des Bodens. Verlagsbuchhandlung Paul Parey, Berlin, 1930.

6. Russell, E. J. Soil Conditions and Plant Growth. Longmans, Green and Co., 1932.

7. Spillman, W. J. Use of the Exponential Yield Curve in Fertilizer Experiments. U.S.D.A., Tech. Bull. 348, 1933.

8. _-_____, and Lang. F. The Law of Diminishing Returns. World Book Co., 2126 Prairie Ave., Chicago, 1924.

9. Wilcox, $\mathbf{0}$. W. The Law of Diminishing Returns Codified, Facts About Sugar, 22(1) : 16-7, 1927. 